\title{
IMPLEMENTATION OF VENOUS THROMBOEMBOLISM PROPHYLAXIS GUIDELINES IN CLINICAL PRACTICE: A RETROSPECTIVE STUDY IN TWO CROATIAN HOSPITALS
}

\author{
Srećko Marušić ${ }^{1}$, Aleksandar Knežević2, Vesna Bačić Vrca ${ }^{3}$, Ivana Marinovićéc Julija Bačić ${ }^{4}$, \\ Paulo Roque Obreli Neto ${ }^{5}$,Daniela Amidžić Klarić ${ }^{3}$ and Dijaneta Diklić ${ }^{2}$ \\ ${ }^{1}$ Department of Clinical Pharmacology, Dubrava University Hospital, University of Zagreb \\ School of Medicine, Zagreb, Croatia; ${ }^{2}$ Medical Department, Zadar General Hospital, Zadar, Croatia; \\ ${ }^{3}$ Department of Clinical Pharmacy, Dubrava University Hospital, Zagreb, Croatia; \\ ${ }^{4}$ Faculty of Pharmacy and Biochemistry, University of Zagreb, Zagreb, Croatia; \\ ${ }^{5}$ Department of Pharmacology and Therapeutics, State University of Maringá, Maringá, PR, Brazil
}

SUMMARY - The aim of this study was to evaluate the implementation of the $9^{\text {th }}$ edition of the American College of Chest Physicians (ACCP9) guidelines for prevention of venous thromboembolism in nonsurgical patients in clinical practice in one university and one general Croatian hospital. A retrospective study was conducted at Zadar General Hospital from Zadar and Dubrava University Hospital from Zagreb. Medical charts of all patients admitted to Medical Departments in two periods, before and after implementation of the ACCP9 guidelines, were analyzed. The ACCP9 guidelines were made available to all physicians through the hospital electronic information system immediately after the publication. The Hospital Drug Committees promoted implementation of the guidelines during their periodical clinical visits. Overall, 850 patients were included in the study in two periods. There was no statistically significant difference in the number of high-risk patients receiving thromboprophylaxis after the guidelines implementation in either hospital. In both periods, a significantly higher number of high-risk patients received thromboprophylaxis in Dubrava University Hospital in comparison with Zadar General Hospital (31.7\% vs. 3.8\% and $40.3 \%$ vs. $7.3 \%$, respectively; $\mathrm{p}<0.001)$. This study revealed insufficient implementation of evidence-based thromboprophylaxis guidelines in clinical practice in two Croatian hospitals.

Key words: Venous thromboembolism; Practice guidelines as topic; Pharmacy and therapeutics committee; Retrospective studies; Croatia

\section{Introduction}

Venous thromboembolism (VTE) comprises deep vein thrombosis (DVT) and pulmonary embolism (PE). It is an important cause of morbidity and mor-

Correspondence to: Srećko Marušić, PhD, Department of Clinical Pharmacology, Dubrava University Hospital, University of Zagreb School of Medicine, Av. Gojka Šuška 6, HR-10000 Zagreb, Croatia

E-mail: srmarusic@inet.hr

Received April 12, 2016, accepted June 13, 2016 tality in hospitalized patients, and treatment of VTE and related long-term morbidities is associated with considerable costs to the health care system ${ }^{1,2}$.

Pulmonary embolism, which is the most serious complication of VTE, is the third most common lifethreatening cardiovascular disease, after myocardial infarction and stroke 3 . It accounts for $5 \%-10 \%$ of deaths in hospitalized patients, making $\mathrm{PE}$ the most common preventable cause of in-hospital deaths ${ }^{4}$. The exact incidence of VTE is difficult to estimate because it is often asymptomatic and unrecognized. The inci- 
dence varies, ranging from 76 to 117 cases $/ 100,000$ patients $^{5-7}$ in the US, and from 160 to 180 cases/100,000 patients in Europe ${ }^{8,9}$. Although VTE is often regarded as a surgical complication, about threequarters of hospitalized patients who suffer a fatal PE are, in fact, medical patients ${ }^{10}$.

The effectiveness and safety of thromboprophylaxis has been supported by the evidence from several randomized clinical trials conducted in medical patients $^{11-13}$. However, underuse of routine thromboprophylaxis has been reported. Three large-scale prevention studies ENDORSE, IMPROVE and DVTFREE showed that appropriate thromboprophylaxis rates in at-risk medical patients varied from $39.5 \%$ to $60.0 \%$ and that thromboprophylaxis rates in surgical patients were higher than in medical patients ${ }^{14-16}$.

Thromboprophylaxis in clinical practice can be improved by the implementation of guidelines for the risk assessment and prevention of VTE. However, there are always physicians who do not apply the guidelines consistently ${ }^{17}$.

The American College of Chest Physicians (ACCP) guidelines for prevention of VTE in nonsurgical patients include recommendations for the risk assessment and prevention of VTE in medical patients ${ }^{18}$. The $9^{\text {th }}$ edition (ACCP9) of the guidelines was published in February 2012 and their implementation in clinical practice has not yet been evaluated.

The aim of the study was to evaluate the implementation of ACCP9 guidelines in clinical practice in two Croatian hospitals, one university and one general.

\section{Patients and Methods}

\section{Study design and setting}

A retrospective study was conducted at two Croatian hospitals, Zadar General Hospital from Zadar and Dubrava University Hospital from Zagreb. The former is a non-teaching hospital with 500 beds; the latter is a university-based teaching hospital with 1000 beds. These hospitals were chosen because of the possible difference in clinical practice between university and general hospitals.

The study was approved by the research Ethics Committees of the Zadar General Hospital and Dubrava University Hospital.

\section{Guideline distribution}

The ACCP9 guidelines for prevention of VTE in nonsurgical patients were published in February 2012. Immediately after the publication, the guidelines became available to all physicians in Zadar General Hospital and Dubrava University Hospital via hospital electronic information system.

Each hospital has a Hospital Drug Committee, which evaluates and promotes the rational use of drugs. The Committee members periodically conduct clinical visits, during which they discuss therapeutic issues with hospital physicians. After distribution of the ACCP9 guidelines, the Hospital Drug Committee evaluated the use of thromboprophylaxis and promoted the implementation of the guidelines during their periodical clinical visits, which took place approximately every three months. Medical records of hospitalized patients were evaluated during the visit and guideline implementation issues were discussed with physicians.

\section{Data collection}

We evaluated medical charts of all patients admitted to the Medical Departments of the Zadar General Hospital and Dubrava University Hospital between January 1 and January 31, 2012, i.e. in the period before the implementation of the guidelines, and between January 1 and January 31, 2013, i.e. in the period after the implementation of the guidelines. For each patient included in the study, we collected data on the assessment of the VTE risk (presence of an active cancer, previous VTE, reduced mobility, known thrombophilic condition, recent ( $\leq 1$ month) trauma and/or surgery, older age ( $\geq 70$ years), heart and/or respiratory failure, acute myocardial infarction or ischemic stroke, acute infection and/or rheumatologic disorder, obesity $(\mathrm{BMI} \geq 30)$, and ongoing hormonal treatment $)^{18}$. Data were entered into an electronic database developed by the researchers for use in the study.

We excluded from the study medical charts of the patients that had an indication for anticoagulation therapy (e.g., DVT, atrial fibrillation) and patients that had an excessive risk of bleeding as defined by the ACCP9 guidelines (active gastroduodenal ulcer, bleeding in 3 months before admission, platelet count $<50 \times 10^{9} / \mathrm{L}$, and multiple risk factors for bleeding $)^{18}$. 


\section{Risk assessment model}

In order to assess the VTE risk and to determine adequacy of thromboprophylaxis, the ACCP9 guidelines for prevention of VTE in nonsurgical patients were used ${ }^{18}$. The guidelines have adopted the Padua Prediction Score risk assessment model, which is based on the principle of assigning points to each of the 11 common VTE risk factors ${ }^{19}$. Using this model, we categorized study patients in two groups: low-risk (score $<4$ ) and high-risk (score $\geq 4$ ) patients.

We reviewed medical charts to identify the use of thromboprophylaxis during hospitalization and to determine whether the study patients were receiving appropriate thromboprophylaxis. For high-risk medical patients, the ACCP9 guidelines recommend the VTE prophylaxis with low molecular weight heparin, low dose unfractionated heparin or fondaparinux. For low-risk medical patients, no thromboprophylaxis is recommended ${ }^{18}$.

\section{Statistical analysis}

We determined the proportion of high-risk and low-risk patients and the proportion of patients re- ceiving adequate prophylaxis. The $\chi^{2}$-test was used to test differences between categorical variables. The values of $p<0.05$ were considered statistically significant. All tabulations and statistical analyses were done using Statistica version 5.5 for Windows (StatSoft Inc. Tulsa, OK, USA).

\section{Results}

Medical charts of 204 patients admitted in January 2012 and of 216 patients admitted in January 2013 to the Medical Department of Dubrava University Hospital were included in the study (Table 1). There was no statistically significant difference in the number of high-risk patients receiving thromboprophylaxis between the two study periods. However, a significantly higher number of low-risk patients received prophylaxis in January 2013.

We included in the study medical charts of $224 \mathrm{pa}^{-}$ tients admitted in January 2012 and of 206 patients admitted in January 2013 to the Medical Department of Zadar General Hospital (Table 2). There was no statistically significant difference in the number of pa-

Table 1. Dubrava University Hospital - thromboprophylaxis in medical patients in January 2012 and January 2013

\begin{tabular}{|l|l|l|l|}
\hline & January 2012 & January 2013 & \multirow{2}{*}{ p value* } \\
\hline Overall number of patients & 204 & 216 & \\
\hline High-risk patients, $\mathrm{n}(\%)$ & $60(29.4)$ & $67(31.0)$ & \\
$\quad$ received prophylaxis, $\mathrm{n}(\%)$ & $19(31.7)$ & $27(40.3)$ & 0.312 \\
$\quad$ not received prophylaxis, $\mathrm{n}(\%)$ & $41(68.3)$ & $40(59.7)$ & \\
\hline Low-risk patients, $\mathrm{n}(\%)$ & $144(70.6)$ & $149(69.0)$ & \\
$\quad$ received prophylaxis, $\mathrm{n}(\%)$ & $8(5.6)$ & $24(16.1)$ & 0.003 \\
$\quad$ not received prophylaxis, $\mathrm{n}(\%)$ & $136(94.4)$ & $125(83.9)$ & \\
\hline
\end{tabular}

${ }^{*} \chi^{2}$ test

Table 2. Zadar General Hospital - thromboprophylaxis in medical patients in January 2012 and January 2013

\begin{tabular}{|c|c|c|c|}
\hline & January 2012 & January 2013 & 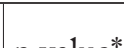 \\
\hline Overall number of patients & 224 & 206 & $p$ value \\
\hline $\begin{array}{l}\text { High-risk patients, } \mathrm{n}(\%) \\
\quad \text { received prophylaxis, } \mathrm{n}(\%) \\
\text { not received prophylaxis, } \mathrm{n}(\%)\end{array}$ & $\begin{array}{l}80(35.7) \\
3(3.8) \\
77(96.2)\end{array}$ & $\begin{array}{l}110(53.4) \\
8(7.3) \\
102(92.7)\end{array}$ & 0.304 \\
\hline $\begin{array}{l}\text { Low-risk patients, } \mathrm{n}(\%) \\
\quad \text { received prophylaxis, } \mathrm{n}(\%) \\
\text { not received prophylaxis, } \mathrm{n}(\%)\end{array}$ & $\begin{array}{l}144(64.3) \\
0 \\
144(100)\end{array}$ & $\begin{array}{l}96(46.6) \\
0 \\
96(100)\end{array}$ & 1.000 \\
\hline
\end{tabular}

${ }^{*} \chi^{2}$ test 
Table 3. Difference in use of thromboprophylaxis in high-risk medical patients between Dubrava University Hospital and Zadar General Hospital

\begin{tabular}{|c|c|c|c|c|}
\hline & & Dubrava University Hospital & Zadar General Hospital & p value* \\
\hline 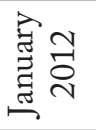 & $\begin{array}{l}\text { Number of patients } \\
\quad \text { received prophylaxis, } \mathrm{n}(\%) \\
\text { not received prophylaxis, } \mathrm{n}(\%)\end{array}$ & $\begin{array}{l}60 \\
19(31.7) \\
41(68.3)\end{array}$ & $\begin{array}{l}80 \\
3(3.8) \\
77(96.2)\end{array}$ & $<0.001$ \\
\hline 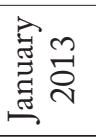 & $\begin{array}{l}\text { Number of patients } \\
\text { received prophylaxis, } \mathrm{n}(\%) \\
\text { not received prophylaxis, } \mathrm{n}(\%)\end{array}$ & $\begin{array}{l}67 \\
27(40.3) \\
40(59.7) \\
\end{array}$ & $\begin{array}{l}110 \\
8(7.3) \\
102(92.7)\end{array}$ & $<0.001$ \\
\hline
\end{tabular}

${ }^{*} \chi^{2}$ test

tients receiving thromboprophylaxis between the January 2012 and January 2013 study periods.

In both periods, high-risk medical patients received thromboprophylaxis significantly more often in Dubrava University Hospital than in Zadar General Hospital (Table 3).

\section{Discussion}

To the authors' knowledge, this is the first study evaluating the implementation of the ACCP9 guidelines in clinical practice. The results indicated that the implementation of the guidelines through the hospital information system and with support of the Hospital Drug Committee did not improve the thromboprophylaxis rate in high-risk medical patients in two Croatian hospitals. Previous studies have also reported insufficient implementation of thromboprophylaxis guidelines. In the study by Amin et al., only 9.8\% of medical patients received thromboprophylaxis in accordance with the guidelines ${ }^{20}$. Obviously, the stricter and immediate education of physicians is needed to overcome the implementation gap ${ }^{21}$. Educational programs have been effective in increasing the rate of thromboprophylaxis ${ }^{22}$.

Surprisingly enough, in Dubrava University Hospital, significantly more low-risk medical patients received thromboprophylaxis after the implementation of the guidelines. This could be the result of physicians' misunderstanding of the guidelines and having difficulties with risk assessment in medical patients. Since the assessment of VTE risk is simpler in surgical patients, it could result in a higher rate of thromboprophylaxis compared with medical patients ${ }^{14-16}$.

Alarmingly high proportions of high-risk medical patients did not receive thromboprophylaxis. These proportions were higher than those reported in previous studies ${ }^{14-16}$. This could be attributed to differences in clinical practice standards and physician education in different countries.

In both study periods, the number of high-risk medical patients receiving thromboprophylaxis was significantly higher in Dubrava University Hospital than in Zadar General Hospital. This difference was probably the result of greater financial resources and better educated physicians in university hospitals. Our results are consistent with the studies conducted in Canada and the USA by Kahn et al..$^{23}$ and Amin et $a .^{24}$, who also report greater use of thromboprophylaxis in university hospitals. Other studies did not detect such difference ${ }^{14-16}$.

\section{Strengths and limitations}

The strength of our study was that we evaluated the implementation of the guidelines in one university hospital and one general hospital. This allowed us to limit the potential bias due to differences in clinical practice, physicians' knowledge, and so on.

The first limitation of our study was the limited quality of collected data due to its retrospective design. For instance, it was not possible to evaluate if the duration of thromboprophylaxis was in accordance with the guidelines, since changes in patient mobility could not be assessed from their medical charts. Another limitation was that we could not control the use of alternative guidelines or standards for thromboprophylaxis, which could have influenced the study results. Also, our study included only two hospitals and the rate of thromboprophylaxis is likely to vary across the hospitals because of the difference in local standards and knowledge. Therefore, the results of our study should be interpreted having these limitations in mind. 
This study demonstrated insufficient implementation of evidence-based thromboprophylaxis guidelines in clinical practice and significant difference between university and general hospitals. Up to more than half of hospitalized medical patients were at a high risk of VTE, but only up to one-third of them received thromboprophylaxis. The proportion of patients receiving thromboprophylaxis did not significantly increase after the implementation of the ACCP9 guidelines. Underuse of VTE prophylaxis will certainly increase in-hospital mortality. To improve patient safety, more effort is needed to increase the extent of implementation of the current thromboprophylaxis guidelines ${ }^{25}$.

\section{References}

1. Martinez C, Cohen AT, Bamber L, Rietbrock S. Epidemiology of first and recurrent venous thromboembolism: a populationbased cohort study in patients without active cancer. Thromb Haemost. 2014;112:255-63. doi: 10.1160/TH15-08-0686

2. Hill J, Treasure T; National Clinical Guideline Centre for Acute and Chronic Conditions. Reducing the risk of venous thromboembolism in patients admitted to hospital: summary of NICE guidance. BMJ. 2010;340:c95. doi: 10.1136/bmj.c95

3. Nielsen JD. The incidence of pulmonary embolism during deep vein thrombosis. Phlebology. 2013;28(Suppl 1):29-33. doi: 10.1177/0268355513477009

4. Alikhan R, Peters F, Wilmott R, Cohen AT. Fatal pulmonary embolism in hospitalised patients: a necropsy review. J Clin Pathol. 2004;57:1254-7. doi: 10.1136/jcp.2003.013581

5. Anderson FA Jr, Wheeler HB, Goldberg RJ, Hosmer DW, Patwardhan NA, Jovanovic B, et al. A population-based perspective of the hospital incidence and case-fatality rates of deep vein thrombosis and pulmonary embolism. The Worcester DVT Study. Arch Intern Med. 1991;151:933-8.

6. Silverstein MD, Heit JA, Mohr DN, Petterson TM, O'Fallon WM, Melton LJ $3^{\text {rd }}$. Trends in the incidence of deep vein thrombosis and pulmonary embolism: a 25 -year populationbased study. Arch Intern Med. 1998;158:585-93.

7. Spencer FA, Emery C, Lessard D, Anderson F, Emani S, Aragam J, et al. The Worcester Venous Thromboembolism study: a population-based study of the clinical epidemiology of venous thromboembolism. J Gen Intern Med. 2006;21:722-7. doi: 10.1111/j.1525-1497.2006.00458.x

8. Oger E. Incidence of venous thromboembolism: a communitybased study in western France. EPI-GETBP Study Group. Groupe d'Etude de la Thrombose de Bretagne Occidentale. Thromb Haemost. 2000;83:657-60.

9. Nordström M, Lindblad B, Bergqvist D, Kjellström T. A prospective study of the incidence of deep-vein thrombosis within a defined urban population. J Intern Med. 1992;232:155-60.
10. Cohen AT, Alikhan R, Arcelus JI, Bergmann JF, Haas S, Merli GJ, et al. Assessment of venous thromboembolism risk and the benefits of thromboprophylaxis in medical patients. Thromb Haemost. 2005;94:750-9.

11. Cohen AT, Davidson BL, Gallus AS, Lassen MR, Prins MH, Tomkowski W, et al. Efficacy and safety of fondaparinux for the prevention of venous thromboembolism in older acute medical patients: randomised placebo controlled trial. BMJ. 2006;332: 325-9. doi: 10.1136/bmj.38733.466748.7C

12. Samama MM, Cohen AT, Darmon JY, Desjardins L, Eldor A, Janbon C, et al. A comparison of enoxaparin with placebo for the prevention of venous thromboembolism in acutely ill medical patients. Prophylaxis in Medical Patients with Enoxaparin Study Group. N Engl J Med. 1999;341:793-800. doi: 10.1056/ NEJM199909093411103

13. Leizorovicz A, Cohen AT, Turpie AG, Olsson CG, Vaitkus PT, Goldhaber SZ; PREVENT Medical Thromboprophylaxis Study Group. Randomized, placebo-controlled trial of dalteparin for the prevention of venous thromboembolism in acutely ill medical patients. Circulation. 2004;110:874-9. doi: 10.1161/ 01.CIR.0000138928.83266.24

14. Cohen AT, Tapson VF, Bergmann JF, Goldhaber SZ, Kakkar $\mathrm{AK}$, Deslandes B, et al. Venous thromboembolism risk and prophylaxis in the acute hospital care setting (ENDORSE study): a multinational cross-sectional study. Lancet. 2008;371:387-94. doi: 10.1016/S0140-6736(08)60202-0

15. Tapson VF, Decousus H, Pini M, Chong BH, Froehlich JB, Monreal M, et al. Venous thromboembolism prophylaxis in acutely ill hospitalized medical patients: findings from the International Medical Prevention Registry on Venous Thromboembolism. Chest. 2007;132:936-45. doi: 10.1378/chest.06-2993

16. Goldhaber SZ, Tapson VF; DVT FREE Steering Committee. A prospective registry of 5,451 patients with ultrasound-confirmed deep vein thrombosis. Am J Cardiol. 2004;93:259-62.

17. Maynard G, Stein J. Designing and implementing effective venous thromboembolism prevention protocols: lessons from collaborative efforts. J Thromb Thrombolysis. 2010;29:159-66. doi: 10.1007/s11239-009-0405-4

18. Kahn SR, Lim W, Dunn AS, Cushman M, Dentali F, Akl EA, et al. Prevention of VTE in nonsurgical patients: antithrombotic therapy and prevention of thrombosis, $9^{\text {th }}$ edition: the American College of Chest Physicians evidence-based clinical practice guidelines. Chest. 2012;141(Suppl 2):195-226. doi: 10.1378/chest.11-2296

19. Barbar S, Noventa F, Rossetto V, Ferrari A, Brandolin B, Perlati $\mathrm{M}$, et al. A risk assessment model for the identification of hospitalized medical patients at risk for venous thromboembolism: the Padua Prediction Score. J Thromb Haemost. 2010; 8:2450-7. doi: 10.1111/j.1538-7836.2010.04044.x

20. Amin A, Spyropoulos AC, Dobesh P, Shorr A, Hussein M, Mozaffari E, et al. Are hospitals delivering appropriate VTE prevention? The venous thromboembolism study to assess the rate of thromboprophylaxis (VTE start). J Thromb Thrombolysis. 2010;29:326-39. doi: 10.1007/s11239-009-0361-z 
21. Maynard G, Jenkins IH, Merli GJ. Venous thromboembolism prevention guidelines for medical inpatients: mind the (implementation) gap.J Hosp Med. 2013;8:582-8. doi: 10.1002/jhm.2071

22. Stinnett JM, Pendleton R, Skordos L, Wheeler M, Rodgers GM. Venous thromboembolism prophylaxis in medically ill patients and the development of strategies to improve prophylaxis rates. Am J Hematol. 2005;78:167-72. doi: 10.1002/ajh.20281

23. Kahn SR, Panju A, Geerts W, Pineo GF, Desjardins L, Turpie AG, et al. Multicenter evaluation of the use of venous throm- boembolism prophylaxis in acutely ill medical patients in Canada. Thromb Res. 2007;119:145-55. doi: 10.1016/j.thromres. 2006.01.011

24. Amin A, Stemkowski S, Lin J, Yang G. Thromboprophylaxis rates in US medical centers: success or failure? J Thromb Haemost. 2007;5:1610-6. doi: 10.1111/j.1538-7836.2007.02650.x

25. Šklebar I, Mustajbegović J, Šklebar D, Cesarik M, Milošević $\mathrm{M}$, Brborović $\mathrm{H}$, et al. How to improve patient safety culture in Croatian hospitals? Acta Clin Croat. 2016;55:370-80.

Sažetak

\title{
PRIMJENA SMJERNICA ZA PROFILAKSU VENSKE TROMBOEMBOLIJE U KLINIČKOJ PRAKSI: RETROSPEKTIVNO ISTRAŽIVANJE U DVJEMA HRVATSKIM BOLNICAMA
}

\author{
S. Marušić, A. Knežević, V. Bačić Vrca, I. Marinović, J. Bačić, P. R. Obreli Neto, D. Amidžić Klarić i D. Diklić
}

Cilj ovoga retrospektivnog istraživanja bio je procijeniti primjenu 9. izdanja smjernica American College of Chest Physicians (ACCP9) za prevenciju venske tromboembolije u nekirurških bolesnika u kliničkoj i općoj bolnici u Republici Hrvatskoj. Istraživanje je provedeno u Općoj bolnici Zadar i Kliničkoj bolnici Dubrava u Zagrebu. Analizirana je medicinska dokumentacija svih bolesnika hospitaliziranih na internističke odjele u razdoblju prije i nakon implementacije smjernica ACCP9. Smjernice su bile dostupne svim liječnicima putem bolničkih informatičkih sustava. Bolnička povjerenstva za lijekove su tijekom periodičkih kliničkih vizita promovirala primjenu smjernica u kliničkoj praksi. U razdoblju prije i nakon implementacije smjernica u istraživanje je uključeno ukupno 850 bolesnika. Niti u jednoj bolnici nije bilo statistički značajne razlike u broju visoko rizičnih bolesnika koji su dobili tromboprofilaksu nakon implementacije smjernica. U oba razdoblja je broj visoko rizičnih bolesnika koji su dobili tromboprofilaksu bio značajno veći u Kliničkoj bolnici Dubrava u odnosu na Opću bolnicu Zadar (31,7\% prema 3,8\% i 40,3\% prema 7,3\%; p<0,001). Rezultati istraživanja ukazuju na nedostatnu implementaciju smjernica za tromboprofilaksu u dvjema hrvatskim bolnicama.

Ključne riječi: Venska tromboembolija; Kliničke smjernice kao tema; Farmaceutska i terapijska komisija; Retrospektivne studije; Hrvatska 